\title{
EFFECT OF TOPSOIL STOCKPILING ON SOIL PROPERTIES AND ORGANIC AMENDMENTS ON TREE GROWTH DURING GOLD MINE RECLAMATION IN GHANA ${ }^{1}$
}

\begin{abstract}
Paul Kofi Nsiah and W. Schaaf ${ }^{2}$
Abstract: Topsoil is a valuable resource and regarded as the most critical and key component in any successful revegetation following mining activities. Consequently, salvaging and stockpiling topsoil for use in future reclamation is encouraged in mine operations. Studies have, however, demonstrated topsoil stockpiling has adverse impacts on soil properties and that stockpiled topsoil would require organic amendment to promote plant growth. This study was therefore undertaken with the hypothesis that (a) topsoil stockpiling as practiced at Newmont Ghana Gold Limited has adverse impacts on soil properties and (b) amending stockpiled topsoil with organic materials, composted sewage sludge and poultry layer manure, promotes the survival and growth of planted trees. A waste rock dump measuring $36 \mathrm{~m}$ by $45 \mathrm{~m}$ was graded and covered with a $70 \mathrm{~cm}$ layer of stockpiled subsoil followed by a $30 \mathrm{~cm}$ layer of stockpiled topsoil. Soil samples, with three replications, were collected at random from the experimental site and from a nearby un-mined, agricultural site used as reference, for determination of $\mathrm{pH}$, nutrients, organic matter, electrical conductivity, effective cation exchange capacity, base saturation, bulk density, and texture. Poultry layer manure (PLM), composted sewage sludge (CSS), and no amendment (control) were the treatments. Pottedseedlings of five forest tree species; Terminalia superba, Terminalia ivorensis, Mansonia altissima, Kola gigantea, and Cedrela odorata; were planted in May 2016, followed by application of $1 \mathrm{~kg}$ and $0.5 \mathrm{~kg}$ (dry weight) of the PLM and the CSS respectively, per tree. Diameter and height data of all planted trees and number of surviving trees were collected twice to determine tree growth and survival. Statistical analysis revealed that topsoil stockpiling did not have any significant adverse impact on the measured soil properties, compared with the reference plot. One-way ANOVA combined with LSD and Duncan post-hoc tests $(\alpha=0.05)$ also indicated no significant influence of organic amendments on tree growth. Competition from herbaceous plants due to ineffective weed control was observed to be the main driving factor hindering survival and growth of planted trees. Further study to compare planting the intended tree species concurrently with ground cover species in the first growing season combined with adequate weed control to influence tree growth and survival at the site, to the application of organic amendments is warranted.
\end{abstract}

Key words: topsoil, mine-reclamation, organic amendment, revegetation, soil properties, trees species

${ }^{1}$ Oral paper to be presented at the 2019 National Meeting of the American Society of Mining and Reclamation, Big Sky, MT. Welcome Back to Montana: The Land of Reclamation Pioneers, June 3-7, 2019. To be published by ASMR, 1305 Weathervane Dr., Champaign, IL 61821.

${ }^{2}$ Paul Kofi Nsiah (presenter), PhD. Student; Wolfgang Schaaf, Professor in Soil Science, Department of Soil Protection and Recultivation, Brandenburg University of Technology, Cottbus-Senftenberg, KonradWachsmann-Allee 6, 03044 Cottbus, Germany. 


\section{Introduction}

Mining operations involve the use of heavy equipment to clear vegetation as well as remove soil and rock fragments, resulting in the disturbance of landscape aesthetics and soil components such as soil horizons and structure, organic matter (OM), soil microbial population, and nutrient cycles that are crucial to supporting plant growth and ecosystem sustenance (CI, 2000; DOEC, 2005). Without proper management and regulations in place, these activities, along with construction of access roads and other ancillary facilities, can potentially result in severe disturbance or complete destruction of the soil and water resources, landscapes, vegetation, and habitats (Wright, 2002; DOEC, 2005; Reuter, 1997). Leaving natural processes alone to repair such damages may take many years; hence, the urgent need to help nature heal itself from such wounds in a relatively short time period through mine land reclamation

Mine land reclamation has been defined as either the restoration of mined land to its pre-mining conditions, or alteration to make it available for another productive use (CI, 2000). Ghana Environmental Assessment Regulations (L.I. 1652), established in 1999, mandates large-scale mine proponents to reclaim their mine lands. However, personal field observations and studies have revealed most disturbed mine sites in Ghana have not been reclaimed (Nsiah, 2008; Nsiah, 2012). Even in cases where mining companies made reclamation attempts, such efforts could not produce any favourable outcome due to the failure in adopting best reclamation management practices. Notable failures have included poor stabilization of slopes against erosion and sedimentation (Nsiah and Schaaf, 2018) and a lack of either topsoil application or amendment with alternative material as a substrate for revegetation during the reclamation process.

Topsoil generally refers to the A horizon of the soil which is usually darker and more fertile than the layer below (subsoil) because of the accumulation of organic matter (Rollett et al., 2015; Wright, 2002). Topsoil is a valuable resource and regarded as the most critical component in any successful reclamation since it contains the building blocks for plant growth; seeds and other plant propagules, soil biota such as fungi and bacteria, OM and much of the more labile plant nutrients that aid in promoting the emergence and growth of pioneer and other planted species on newly reclaimed lands (Wright, 2002; DOEC, 2005; CI, 2000; Reuter, 1997). Hence, salvaging and stockpiling topsoil during mining and reserving it for future use is critical to ensuring successful reclamation (Reuter, 1997; CI, 2000, Wright, 2002). Consequently, Newmont Ghana Gold 
Limited (NGGL) a mining company operating surface mines at Kenyase in the Brong-Ahafo Region of Ghana, salvages all topsoil and stockpiles it for future reclamation. Additionally, all subsoil is stripped and stockpiled separately.

Long-term topsoil stockpiling has been shown to decrease soil organic matter (SOM) content due to oxidation reactions by soil microbes (Wells and Potter, 1986). Other studies have demonstrated topsoil stripping and stockpiling to have major adverse effects on the physical, chemical and biological properties of the soil resource such as loss of OM (Akala and Lal, 2000; Visser et al, 1984; Abdul-Kareem and McRae, 1984; DOEC, 2005); reduction in the populations of essential microbes such as bacteria, fungi, actinomycetes and algae (Miller and Cameron, 1976); as well as mycorrhizal infection potential (Stark and Redente, 1987). Other effects include compaction and consolidation during storage which deteriorate soil structure (Harris et al., 1989). These reports suggest topsoil stockpiling can eventually lead to reduced nutrient cycling and lower availability of nutrients (Stark and Redente, 1987; DOEC, 2005), which can potentially impair the entire revegetation and reclamation success (Reuter, 1997).

Organic amendment (OA) has been demonstrated to contain high quantities of major plant nutrients and can also be a valuable source of OM, which can improve soil physical, chemical, and biological properties (Larney and Angers, 2012; Wall, 2014) following disturbances such as mining. Organic amendment is a collective term used to describe materials rich in OM that are either a by-product of an existing process, such as biosolids (i.e., treated sewage sludge), or materials that have been produced as a result of some form of recycling process, such as compost (SNIFFER, 2010). Bending et al. (1999) maintain that SOM content, nutrient supply, and pH are usually the most important determinants of the suitability of a disturbed site for restoration. Subsequently, Wright (2002) and DOEC (2005) emphasised applying OA with stockpiled topsoil (TSP) as a vital management practice to improve the supply of nutrients and soil physical and chemical characteristics. Using OA for reclamation has also been described as being mutually beneficial wherein waste products from agriculture, forestry and urban areas help to meet land reclamation goals (Larney and Angers, 2012; Reuter, 1997). Consequently, NGGL applies composted sewage sludge (CSS) as OA with the TSP to enhance revegetation success during reclamation.

In this study, the effect of topsoil stockpiling on soil properties and OA on tree growth were investigated. The hypothesis was that (a) topsoil stockpiling at NGGL will cause significant 
adverse impacts on soil properties and (b) amendment of TSP with organic materials like composted sewage sludge and poultry layer manure will significantly promote survival and growth of planted trees at the site.

\section{Methods}

Site location and description

The study was conducted at an active surface mine site of NGGL located between latitudes $6^{\circ} 40^{\prime}, 7^{\circ} 15^{\prime}$, North and longitudes $2^{\circ} 15^{\prime}$, and $2^{\circ} 45^{\prime}$ West, in Kenyase of the Brong-Ahafo Region, Ghana (Fig. 1).

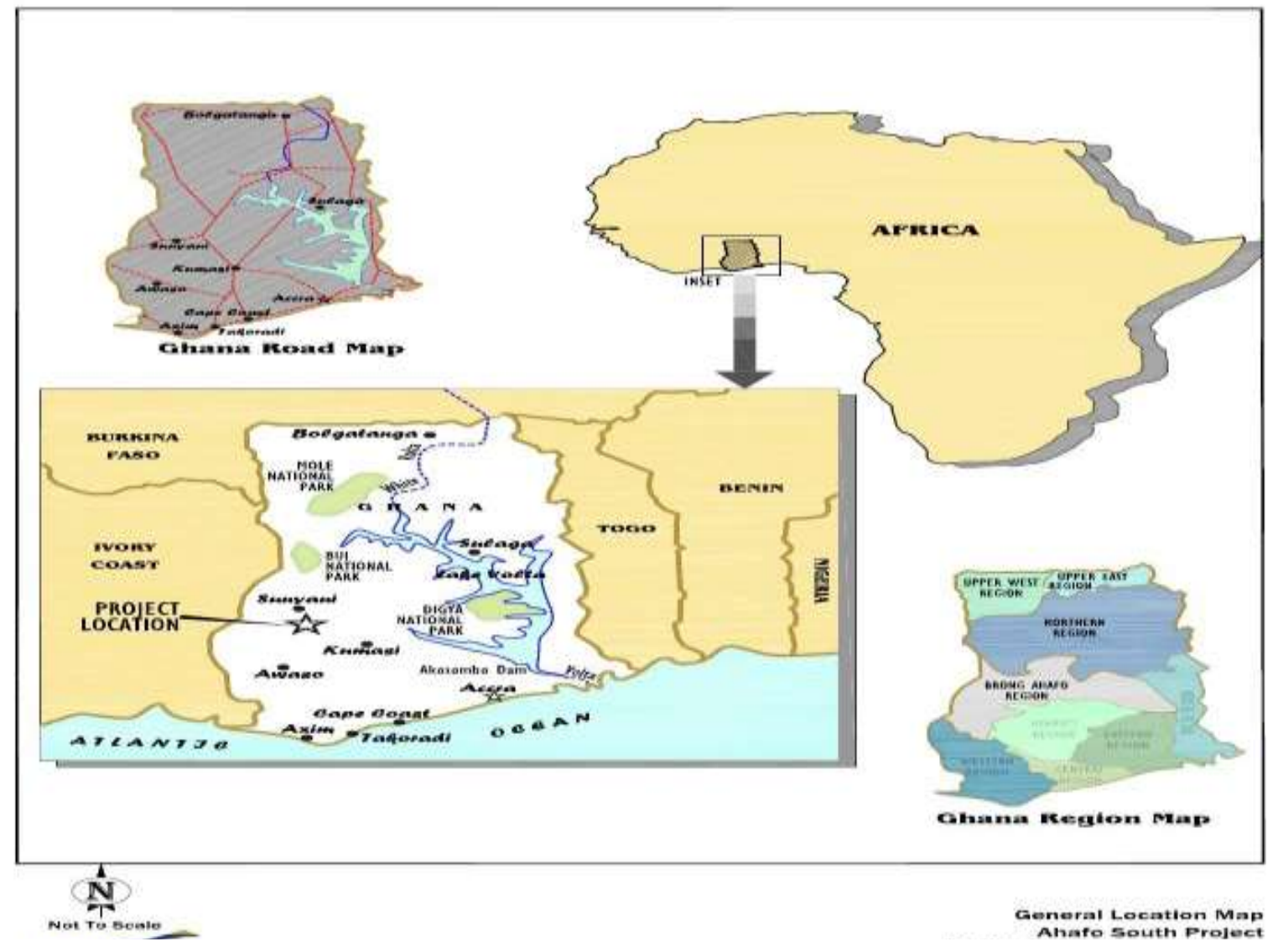

Figure 1. The site location of NGGL, Ahafo-South, Kenyase (Source: NGGL, 2015).

The NGGL Ahafo-South project comprises facilities and services for mining and processing of approximately 105 million tonnes of ore being extracted from four open pits. The area falls within the wet semi-equatorial climatic zone of Ghana and is characterized by an annual double maxima rainfall pattern occurring from mid-March to early July and from early September to midNovember, with mean annual rainfall of 1,232 $\mathrm{mm}$ (Nsiah and Schaaf, 2018). The climate is warm 
and humid with mean monthly temperatures ranging from $23.9^{\circ} \mathrm{C}$ to $28.4^{\circ} \mathrm{C}$. The soils are classified according to the USDA Soil Taxonomy and the FAO World Reference Base as Ultisols (Acrisols and Nitisols) on the uplands and Fluvents (Fluvisols) and Inceptisols (Cambisols) in the lowlands (NGGL, 2015). The area lies within the Moist Semi-Deciduous Zone Northwest Subtype with emergent tall trees often exceeding $50 \mathrm{~m}$ in height (Hall and Swaine, 1981).

\section{$\underline{\text { Land reclamation methods }}$}

The field trial was conducted on a waste rock dump, generated from the excavation and extraction of rocks that surrounded gold-bearing ore at the Amoma Pit, but which did not contain the metal in commercial quantities. Both the topsoil and subsoil were separately salvaged and stockpiled by the company prior to mining in 2009 for replacement during the reclamation phase. In order to maintain soil quality upon stockpiling, the salvaged topsoil was covered with biological geotextiles (BGTs) to control erosion and seeded with deep-rooted perennial plants in 2009. A site measuring $36 \mathrm{~m}$ (vertical) by $45 \mathrm{~m}$ (horizontal) was demarcated for this experiment under a concurrent reclamation approach. The waste rock dump was evenly graded to form a three(vertical) to one-horizontal (3:1) slope and evenly covered with a $70 \mathrm{~cm}$ layer of stockpiled subsoil, followed by a $30 \mathrm{~cm}$ layer of the TSP (Fig. 2), generating a substrate depth of $1 \mathrm{~m}$ for revegetation.
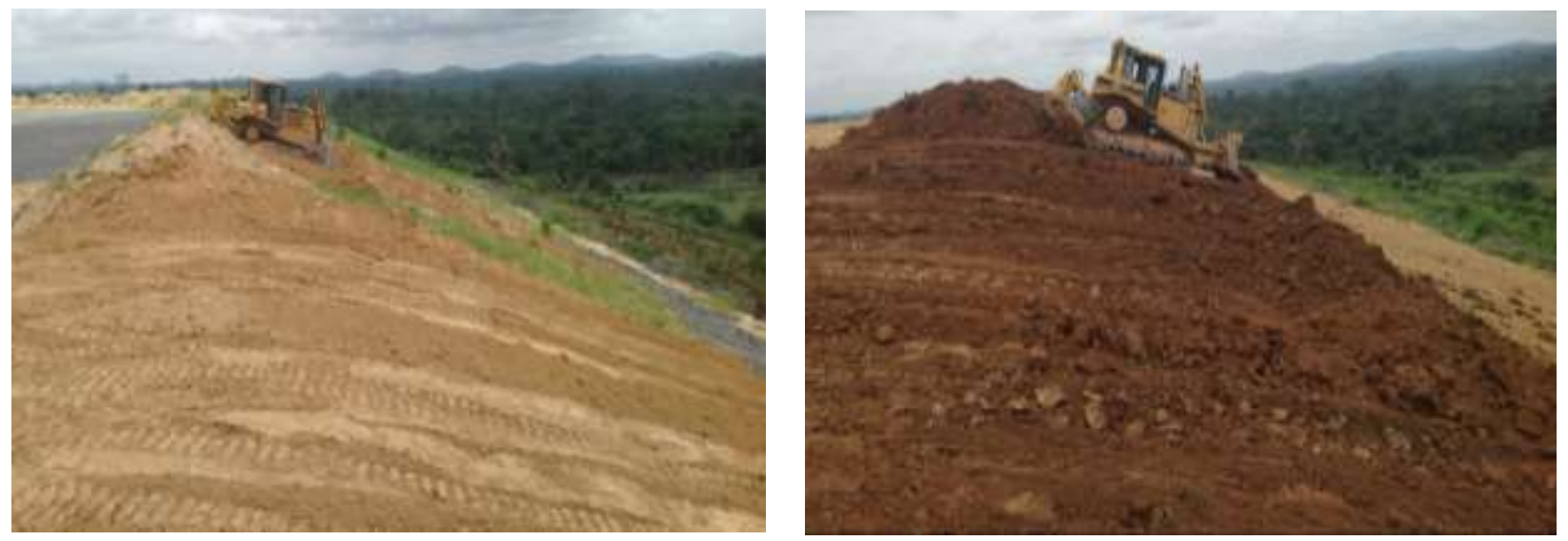

Figure 2. Replacement of stockpiled subsoil (left) and stockpiled topsoil (right).

The site was then scarified (ripped) across the slope to a depth of about $20 \mathrm{~cm}$ (Fig. 3) to minimize compaction and promote surface roughening and water infiltration. Further soil stabilization treatments included installation of "York" mat BGTs for erosion and sediment control (Nsiah and Schaaf, 2018), seeding bermuda grass (Cynodon dactylon) as cover crop and vegetative plantings of Vetiver grass (Chrysopogon zizanioides) in parallel terraces across the slope (Fig. 3). 

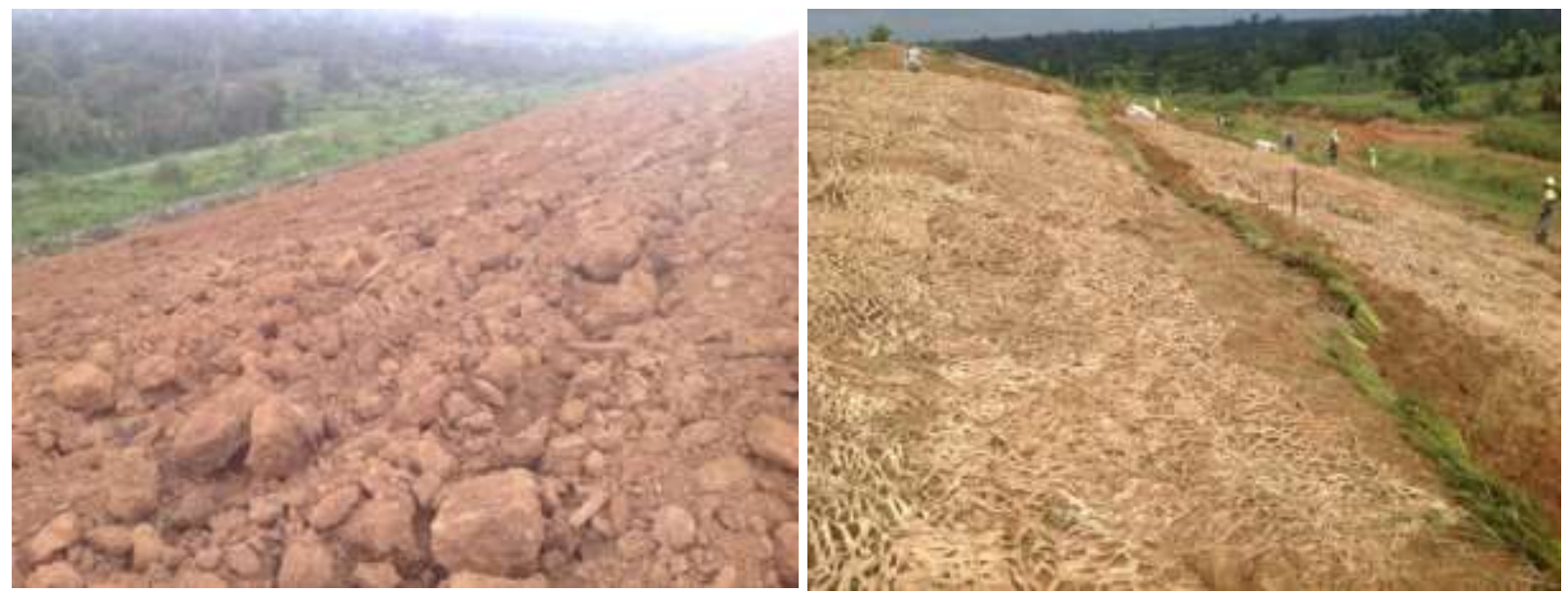

Figure 3. Scarification after TSP re-instatement (left), BGTs installation and vegetative planting of Vetiver grass stalks (right).

$\underline{\text { Soil sampling and analyses }}$

In order to evaluate any influence of topsoil stockpiling on soil properties, soil samples were randomly taken from six soil cores to a depth of $30 \mathrm{~cm}$ (depth of the replaced topsoil) with soil auger in May, 2016. All six samples were placed in a clean plastic bucket to make one composite sample. After some mixing in the bucket, the content was placed onto a clean plastic tray for further mixing and division until a representative sample of about $1 \mathrm{~kg}$ was placed in a brown paper bag (Motsara and Roy, 2008). According to Larney and Angers (2012), a prevalent feature of degraded or disturbed soils is low organic matter content compared with adjacent undisturbed areas. Therefore, six soil cores were taken to a depth of $30 \mathrm{~cm}$ from a nearby un-mined site and bulked to make a single composite sample that was used as a reference (REF) in judging the quality of the TSP. The reference site was a Cocoa (Theobroma cacao) farm, as the land surrounding the mine site had been affected by various farming activities. Separate samples were taken with a $100 \mathrm{~cm}^{3}$ metal ring core to a depth of $4 \mathrm{~cm}$ for bulk density determination. All soil samples were taken with three replications and sent to the laboratory for determination of $\mathrm{pH}$, nutrients, SOM, electrical conductivity (EC), effective cation exchange capacity (ECEC), base saturation (BS), bulk density, and texture.

Prior to analyses, all soil samples, except those used for bulk density determination, were airdried and sieved through a 2-mm mesh. Soil $\mathrm{pH}$ and conductivity were determined using multiparameter PC 300 series electrode in 5:1 soil to water suspension (Motsara and Roy, 2008). Total phosphorus $(\mathrm{P})$ was determined by the blue complex molybdate and thiophosphate in acid solution 
and analyzed using Buck Scientific Spectrophotometer (BSS) model 280 G (Motsara and Roy, 2008). For exchangeable bases, sodium (Na) and potassium (K), were determined by volumetric Sodium tetraphenyl boron method after dry-ashing digestion of the soil sample and analyzing with a Jenway flame photometer model PFP7, whilst that of calcium $(\mathrm{Ca})$ and magnesium $(\mathrm{Mg})$ were analyzed using a Spectrophometer (BSS 280 G) after extraction by ammonium acetate (Motsara and Roy, 2008). Exchangeable acidity due to hydrogen $(\mathrm{H})$ and aluminum (Al) was extracted using $0.1 \mathrm{~N} \mathrm{KCl}$ solution and the filtrate titrated with $0.05 \mathrm{~N} \mathrm{NaOH}$ to colorless end point. Exchangeable acidity ( $\mathrm{Al}$ and $\mathrm{H}$ ) was determined by adding $4 \mathrm{mls}$ of $3 \mathrm{~N}$ to the extract and titrated with $0.05 \mathrm{~N} \mathrm{HCl}$ to a pink end point.

The ECEC was calculated as the sum of exchangeable bases and acidity, and BS was calculated as the percentage of the base cations ( $\mathrm{Na}, \mathrm{K}, \mathrm{Mg}$, and Ca) of ECEC (Hazelton and Murphy, 2007). Loss of weight on ignition method was employed for the determination of SOM and organic amendment samples with the aid of a muffle furnace model L9/S (Motsara and Roy, 2008). Particle size analysis was conducted by the hydrometer method (Bouyoucos, 1931) and textural class was determined according to the United States Department of Agriculture soil texture classification system. Bulk density was determined using undisturbed soil cores collected in a $100 \mathrm{~cm}^{3}$ metal ring core and weight was determined after oven-drying (Brady and Weil, 2008).

Tree planting and organic amendment application

The demarcated site was divided into three experimental plots each measuring $36 \mathrm{~m}$ by $15 \mathrm{~m}$ and the following OA treatments were randomly assigned:

- $\quad$ no amendment (control).

- $\quad$ amendment with poultry layer manure (PLM).

- $\quad$ amendment with composted sewage sludge (CSS).

In May 2016, six-month old potted-seedlings (nursery transplants) of the indigenous tree species Terminalia superba, Terminalia ivorensis, Mansonia altissima, and Kola gigantea together with Cedrela odorata (exotic species) were selected for planting. For each treatment, 15 seedlings each of T. superba and C. odorata and nine seedlings each of T. ivorensis, M. altissima and K. gigantea were randomly planted at a spacing of $3 \mathrm{~m} \times 3 \mathrm{~m}$, with the help of bamboo pegs which were not in regular lines, resulting in an approximate density of 1,100 trees per hectare. Four of the species, T. superba, T. ivorensis, M. altissima, and K. gigantea, were selected because they are native to 
the region whereas $C$. odorata, though an exotic species, was selected for its high adaptability and fast growth rate. Additional selection criteria were based on their high commercial values (high demand for their wood products both locally and abroad) and availability of their seedlings in the local nurseries. Some of the seedlings were obtained from the NGGL nursery stock whereas others were purchased from a nursery stock belonging to the University of Energy and Natural Resources, Sunyani, in the Brong-Ahafo Region of Ghana.

Two weeks after tree planting, the PLM and the CSS were applied to each of the individual trees in their respective plots by first digging a $10 \mathrm{~cm}$ deep trench with a $50 \mathrm{~cm}$ diameter around each planted tree, followed by placement of the respective amendment material, and finally covering with soil. The PLM was applied at a rate of $1 \mathrm{~kg}$ (dry weight) per tree giving a total of 1.1 tonne per hectare, whereas the CSS was applied at a rate of $0.5 \mathrm{~kg}$ (dry weight) per hectare making a total of 0.55 tonne per hectare. The PLM, obtained from a layer-poultry farm, was in abundance, but the CSS, received from NGGL's Sewage Treatment Plant after composting, was of a limited quantity which necessitated the relatively lower application rate of the CSS. Additionally, prior to their application, both amendment materials were also analysed for nutrient and $\mathrm{OM}$ compositions after oven-drying and sieving through a 2-mm mesh (Table 1).

Table 1. Mean chemical composition (standard deviation, sd) of the applied organic amendment materials, PLM and CSS.

\begin{tabular}{|c|c|c|c|c|c|c|c|c|c|c|}
\hline Parameter & $\mathrm{pH}$ & $\begin{array}{l}\mathrm{N} \\
(\%)\end{array}$ & $\begin{array}{l}\mathrm{P} \\
(\%)\end{array}$ & $\begin{array}{l}\mathrm{K} \\
(\%)\end{array}$ & $\begin{array}{l}\mathrm{S} \\
(\%)\end{array}$ & $\begin{array}{l}\mathrm{Ca} \\
(\%)\end{array}$ & $\begin{array}{l}\mathrm{Mg} \\
(\%)\end{array}$ & $\begin{array}{l}\text { OM } \\
(\%)\end{array}$ & $\begin{array}{l}\text { OC } \\
(\%)\end{array}$ & $\begin{array}{l}\mathrm{C} / \mathrm{N} \\
\text { ratio }\end{array}$ \\
\hline PLM & 6.63 & 4.44 & 0.45 & 2.06 & 0.28 & 25.50 & 0.20 & 73.45 & 42.60 & 9.65 \\
\hline$(\mathrm{sd})$ & $(0.12)$ & $(0.01)$ & $(0.01)$ & $(0.03)$ & $(0.02)$ & $(0.71)$ & $(0.00)$ & $(1.49)$ & $(0.86)$ & $(0.25)$ \\
\hline CSS & 6.61 & 3.33 & 0.56 & 0.79 & 0.35 & 10.70 & 1.05 & 40.45 & 23.49 & 7.40 \\
\hline$(\mathrm{sd})$ & $(0.02)$ & $(0.57)$ & $(0.01)$ & $(0.18)$ & $(0.01)$ & $(0.42)$ & $(0.07)$ & $(0.28)$ & $(0.17)$ & $(0.65)$ \\
\hline
\end{tabular}

Tree growth and survival

To evaluate the effects of organic amendments on tree growth and survival, diameter and height of all planted trees as well as number of surviving trees were taken twice, 7 months 
(December, 2016) and 14 months (July, 2017), after planting. Tree height was measured from the soil to the apex of the tree crown using a tape measure, whilst basal stem diameter was taken at 10 $\mathrm{cm}$ above the soil surface with the aid of a veneer calliper. The survival of each tree species was expressed as a percentage by dividing the number of trees surviving by the initial number planted and multiplying by 100 .

$\underline{\text { Statistical analyses }}$

All statistical analyses were performed with IBM SPSS Statistics Version 25.0. The first study hypothesis, effect of topsoil stockpiling on soil properties, was statistically tested using the independent samples t-test $(\mathrm{n}=3)$, by comparing soil parameters (dependent variables) of TSP and REF, at 95\% confidence interval $(\alpha=0.05)$. In addition, results of the analysed TSP were compared mathematically with baseline soil data obtained by the Soil Research Institute of Ghana before mining operations at the site (Adu, 2012). In order to test the second hypothesis, data on tree diameter $(\mathrm{cm})$ and height $(\mathrm{m})$ were first split into five groups based on tree species and then analysed separately using one-way ANOVA combined with LSD and Duncan post-hoc tests $(\alpha=$ $0.05)$ to determine OA treatment difference on tree growth.

\section{$\underline{\text { Results }}$}

\section{Effects of topsoil stockpiling on soil properties}

The results of this study revealed that stockpiling topsoil for a period of seven years at the Amoma Pit did not result in any significant adverse impact on the general topsoil properties, as compared with the REF (Table 2) and baseline soil data (Table 3). Soil organic matter content of the TSP was very high and significantly greater than that of the REF; whilst the recorded mean $\mathrm{pH}$ in the TSP was less acidic than the REF. Total N concentration in the TSP was moderate and significantly greater than the REF which was very low; however, P concentration was the same in both sites. Potassium concentrations were low at both sites, but was significantly greater in the REF than in the TSP. Whilst Mg was moderate and statistically the same in the REF and TSP plots, Ca was high on both sites, but significantly greater in the REF plot.

The concentrations of acidic cations, $\mathrm{H}$ and $\mathrm{Al}$, were not statistically different between treatments. Potassium and $\mathrm{Ca}$ concentrations were significantly greater in the REF plot, which contributed to a corresponding significantly greater calculated ECEC in the REF plot than in the TSP plot. On the contrary, the calculated percentage base saturation for the TSP treatment and the 
REF plot were statistically the same. Electrical conductivity, a measure of soil salinity (Brady and Weil, 2008), was also significantly greater in the REF plot than in the TSP plot, although both were within the acceptable limits for vegetation establishment. The higher SOM concentration in the TSP plot contributed to greater concentration of organic carbon (OC). This, coupled with the relatively higher total $\mathrm{N}$ concentration in the TSP treatment, resulted in significantly lower carbonnitrogen $(\mathrm{C}: \mathrm{N})$ ratio in the TSP plot than the REF plot. The TSP plot contained significantly greater percentage of silt and clay but significantly less sand content than the REF plot, thus yielding a texture of clay-loam for the TSP plot and sandy-clay-loam for the REF plot. That different proportion of sand, silt, and clay was associated with significantly higher bulk density in the TSP than in the REF plots.

Table 2. Soil chemical and physical characteristics of stockpiled topsoil (TSP) and soil from the reference site (REF).

\begin{tabular}{|c|c|c|c|}
\hline Parameter & TSP & REF & $\mathrm{P}$ value \\
\hline $\mathrm{pH}$ & $6.2(0.19)$ & $5.5(0.03)$ & \\
\hline $\mathrm{EC}\left(\mu \mathrm{S} \mathrm{cm}^{-1}\right)$ & $407.30(80.64) \mathrm{a}$ & $228.30(1.53) b$ & 0.018 \\
\hline $\mathrm{N}(\%)$ & $0.11(0.01) \mathrm{a}$ & $0.07(0.002) b$ & 0.001 \\
\hline $\mathrm{P}(\%)$ & $0.31(0.001) \mathrm{a}$ & $0.31(0.002) \mathrm{a}$ & 1.000 \\
\hline $\mathrm{K}\left(\mathrm{Cmol}_{\mathrm{c}} \mathrm{kg}^{-1}\right)$ & $0.04(0.00) b$ & $0.08(0.006) \mathrm{a}$ & 0.001 \\
\hline $\mathrm{Mg}\left(\mathrm{Cmol}_{\mathrm{c}} \mathrm{kg}^{-1}\right)$ & $0.57(0.63) \mathrm{a}$ & $0.67(0.10) \mathrm{a}$ & 0.725 \\
\hline $\mathrm{Ca}\left(\mathrm{Cmol}_{\mathrm{c}} \mathrm{kg}^{-1}\right)$ & $6.80(1.09) b$ & $9.80(0.40) \mathrm{a}$ & 0.012 \\
\hline $\mathrm{Na}\left(\mathrm{Cmol}_{\mathrm{c}} \mathrm{kg}^{-1}\right)$ & $0.71(0.22) \mathrm{a}$ & $0.98(0.01) \mathrm{a}$ & 0.099 \\
\hline $\mathrm{H}\left(\mathrm{Cmol}_{\mathrm{c}} \mathrm{kg}^{-1}\right)$ & $0.65(0.23) \mathrm{a}$ & $0.40( \pm 0.04) \mathrm{a}$ & 0.143 \\
\hline $\left.\mathrm{Al} \mathrm{Cmol}_{\mathrm{c}} \mathrm{kg}^{-1}\right)$ & $0.34(0.13) \mathrm{a}$ & $0.39(0.08) \mathrm{a}$ & 0.435 \\
\hline $\operatorname{ECEC}\left(\mathrm{Cmol}_{\mathrm{c}} \mathrm{kg}^{-1}\right)$ & $9.91(0.24) b$ & $12.32(0.07) \mathrm{a}$ & 0.001 \\
\hline Base saturation (\%) & $82.69(9.45) \mathrm{a}$ & $93.56(0.37) \mathrm{a}$ & 0.118 \\
\hline
\end{tabular}


Journal American Society of Mining and Reclamation, 2019 Vol.8, No.1

\begin{tabular}{llll}
\hline OM $(\%)$ & $6.20(0.08) \mathrm{a}$ & $5.80(0.01) \mathrm{b}$ & 0.003 \\
OC $(\%)$ & $3.60(0.04) \mathrm{a}$ & $3.40(0.01) \mathrm{b}$ & 0.002 \\
C/N Ratio & $32.29(2.5) \mathrm{b}$ & $50.96(1.2) \mathrm{a}$ & 0.001 \\
bulk density $\left(\mathrm{g} \mathrm{cm}^{-3}\right)$ & $1.53(0.03) \mathrm{a}$ & $1.32(0.01) \mathrm{b}$ & 0.001 \\
Sand (\%) & $40.75(2.79) \mathrm{b}$ & $57.74(0.45) \mathrm{a}$ & 0.001 \\
Silt $(\%)$ & $27.99(2.16) \mathrm{a}$ & $16.08(0.71) \mathrm{b}$ & 0.001 \\
Clay $(\%)$ & $31.26(1.05) \mathrm{a}$ & $26.52(0.41) \mathrm{b}$ & 0.001 \\
Clay-loam & Sandy clay-loam &
\end{tabular}

Data were analysed using independent-samples t-test at $\alpha=0.05 ; \mathrm{n}=3$; numbers are means with standard deviations in brackets; within a row, means followed by a different letter are significantly different.

A direct comparison of the results on soil properties with that of baseline soil data obtained by the Soil Research Institute of Ghana before mining operations (Adu, 2012) further confirmed topsoil did not generate any adverse impact on the soil properties since the soil values in the TSP treatment plot were within the ranges of the baseline data (Table 3 ).

Table 3. Baseline soil properties before mining operations at NGGL.

\begin{tabular}{lllll}
\hline Parameter & baseline data (mean) & Baseline data (range) & TSP & REF \\
\hline $\mathrm{pH}$ & 6.2 & $5.5-6.6$ & 6.2 & 5.5 \\
$\mathrm{OM}(\%)$ & 3.2 & $1.5-4.2$ & 6.2 & 5.8 \\
$\mathrm{~N}(\%)$ & 0.17 & $0.08-0.39$ & 0.11 & 0.07 \\
$\mathrm{ECEC}$ & 16.48 & $6.4-34$ & & \\
Base saturation $(\%)$ & 98.5 & $98-99$ & 9.91 & 12.32 \\
& & & 82.69 & 92.89 \\
\hline
\end{tabular}




\section{Effects of organic amendment on tree survival}

Seven months after tree planting and amendment application, there was no significant influence of OA on survival of trees in the five-timber species (Fig. 4).
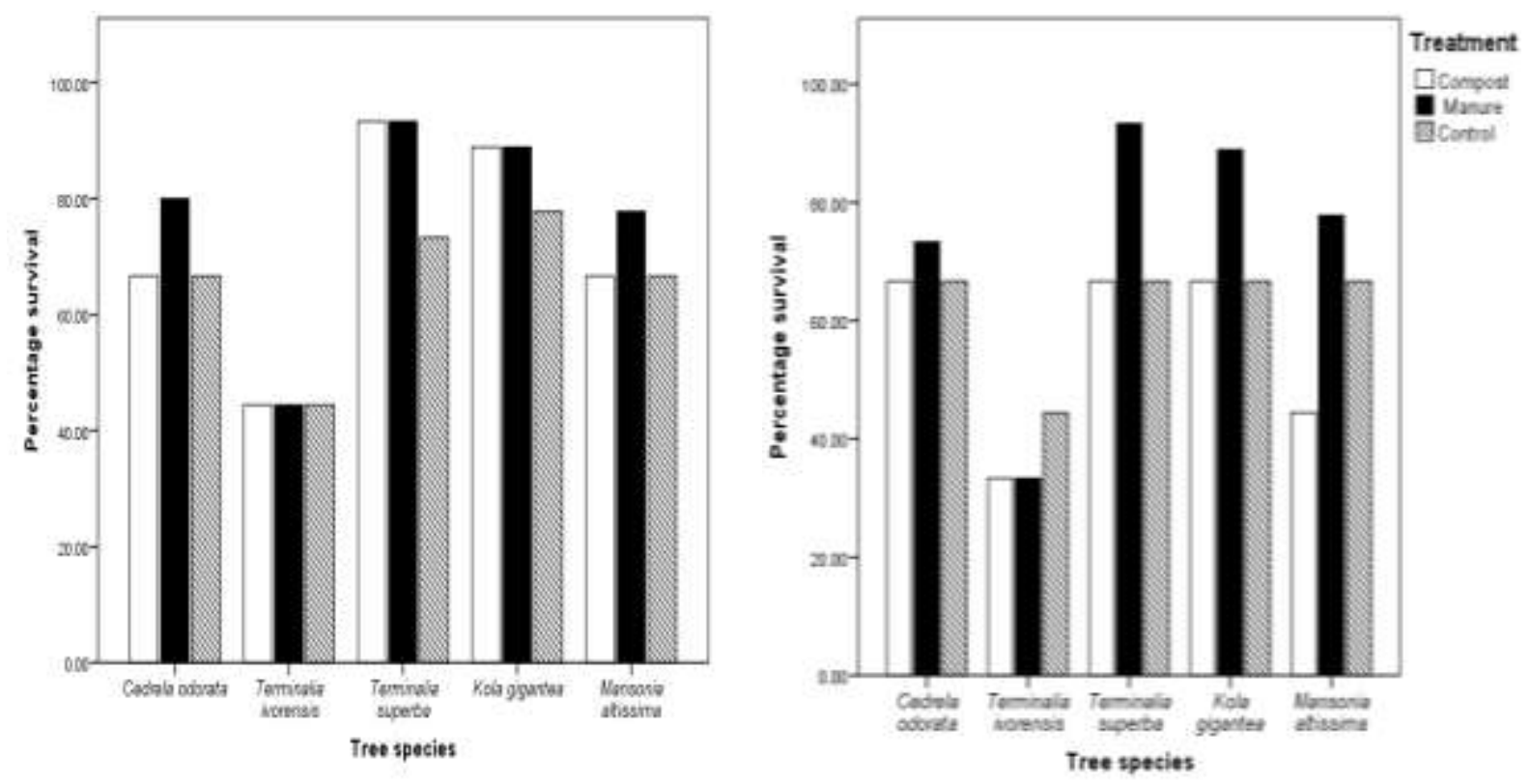

Figure 4. Effect of OA on survival (\%) of five forest tree species 7 months (left) and 14 months right) after planting in a reclaimed mine site at NGGL.

Terminalia superba recorded the highest (93.3\%) in both compost (CSS) and PLM, but 73.3\% in control, followed by K. gigantea (88.9\%) in both CSS and PLM, but $77.8 \%$ in control. Whereas survival of C. odorata (80.0\%) and M. altissima (77.8\%) differed slightly in poultry manure, the two species had the same survival of approximately $67.8 \%$ in both compost and control for the two species. Terminalia ivorensis exhibited the lowest survival rate and yielded the same value of $44.4 \%$ in all treatments.

In like manner, the second assessment did not record any significant changes in tree survival resulting from amendment application after 14 months (Fig. 4). In the PLM treatment, C. odorata and T. ivorensis exhibited further reductions in survival, $77.3 \%$ and $33.3 \%$, respectively. The other three species, T. superba, K. gigantea and M. altissima exhibited no further mortalities, and maintained their previous survival percentage of 93.3\%, 88.9\%, and 77.8\%, respectively (Fig. 4). The control exhibited a similar pattern with no further deaths recorded for C. odorata, M. altissima and T. ivorensis, thus maintaining their previous survival rate of $67.7 \%$ for both $C$. odorata and M. altissima and $44.4 \%$ for T. ivorensis. In contrast, $T$. superba and K. gigantea recorded further mortalities during this period, thereby reducing the survival to $66.7 \%$ for both species. 
The compost treatment yielded the highest mortality among the species. Mortality occurred in three out of the five species in the period between the first and second assessments. There were sharp reductions in survival for $T$. superba and $K$. gigantea, both reducing to $66.7 \%$; whereas $T$. ivorensis exhibited a moderate decline in survival to $33.3 \%$. Cedrela odorata and M. altissima maintained their previous values of 66.7 and $44.4 \%$, respectively, as there were no further mortalities.

\section{Effects of OA on tree growth}

Seven months after planting, OA did not significantly influence either diameter (D) or height (H) growth among the five planted species, all $\mathrm{p}$ values $\leq 0.05$. Cedrela odorata exhibited the most growth in the PLM treatment. followed by the CSS, treatment with the control exhibiting the least growth (Fig. 5).
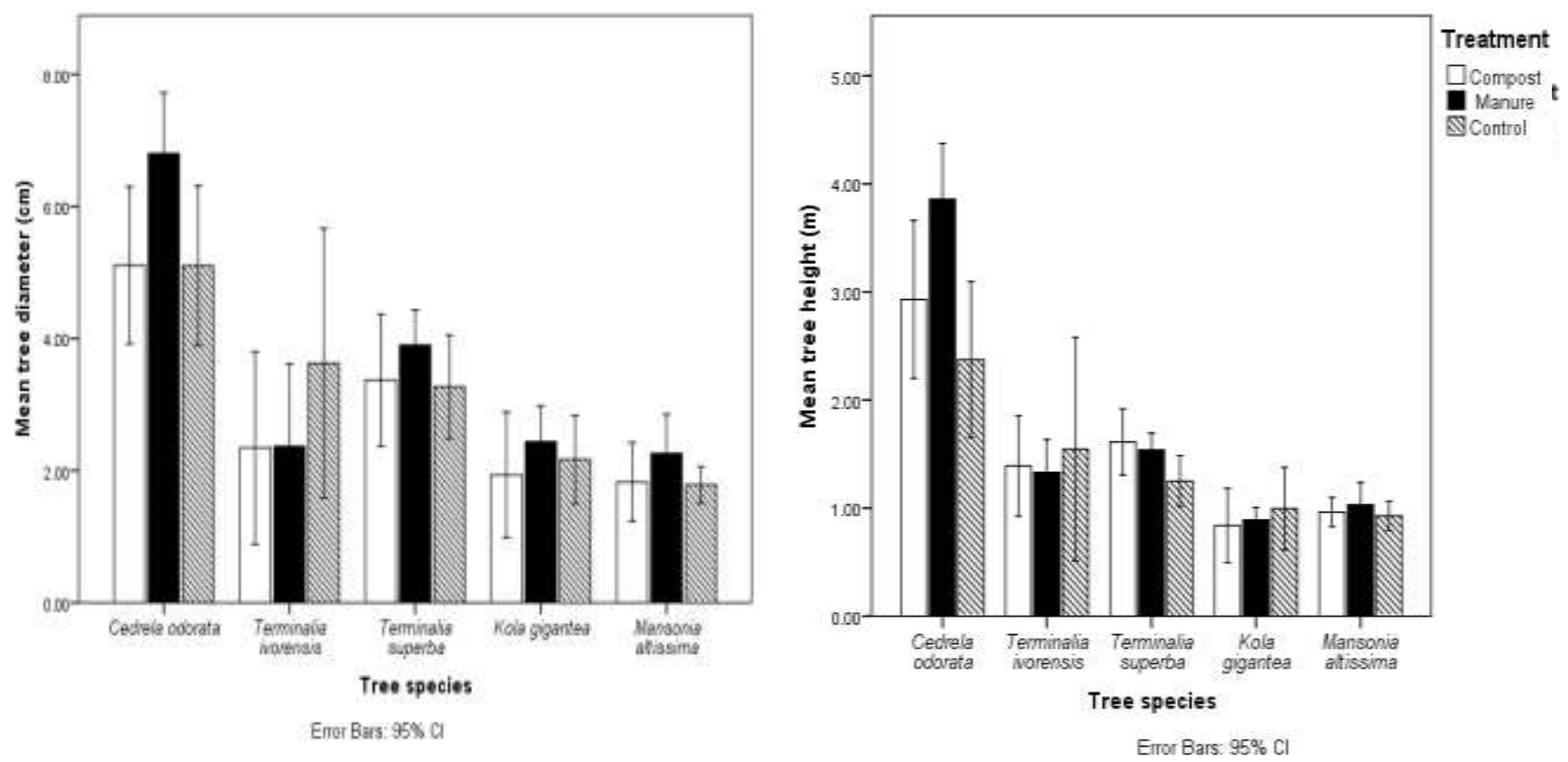

Figure 5. Effect of organic amendment on diameter (left) and height (right) growth (mean values of $n=3$, error bars represent $95 \%$ confidence interval) of five forest tree species seven months after planting and amendment application at NGGL.

Likewise, $T$. superba and $K$. gigantea showed a similar growth pattern, both exhibiting the most growth in the PLM treatment, followed by the CSS treatment, and least growth in the control. Even though T. ivorensis displayed the most growth in the PLM treatment, this was followed by the control, with the CSS treatment exhibiting the least growth. 
During the second growth assessment 14 months after planting and amendment application, OA did not affect diameter growth among any of the planted species (Fig. 6).
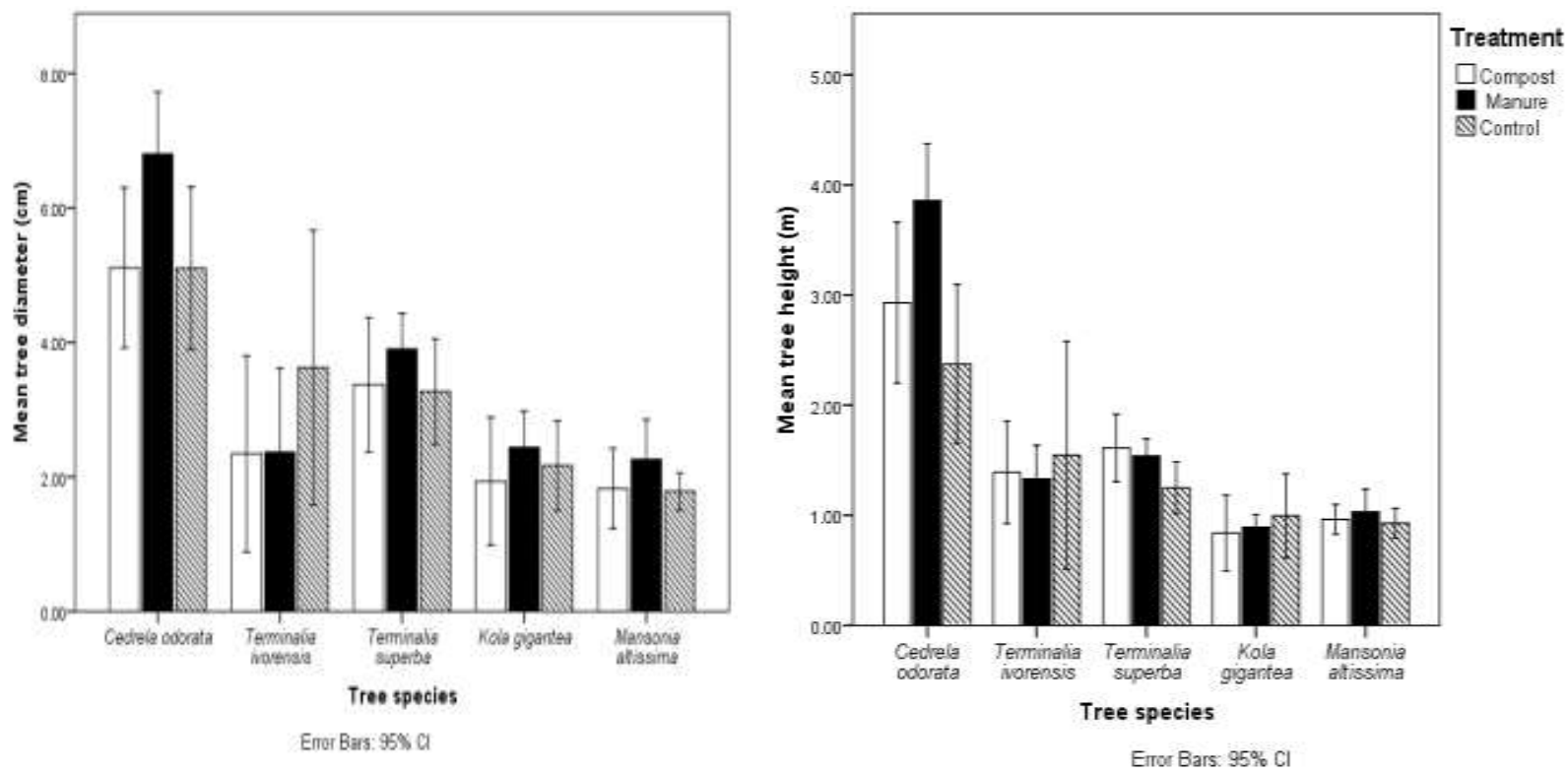

Figure 6. Effect of OA on diameter (left) and height (right) growth (mean values of $n=3$, error bars represent $95 \%$ confidence interval) of five forest tree species 14 months after planting and amendment application at NGGL

With the exception of $T$. ivorensis which had the greatest diameter growth in the control, all the other species recorded greatest diameter growth in the PLM, although the values were not statistically different among OA treatment plots. Cedrela odorata exhibited a slightly significant greater height growth in the PLM treatment than the CSS treatment and the control. None of the other species exhibited significant dominance (Fig. 5 and 6). Tree species $C$. odorata and $M$. altissima displayed the greatest growth in the PLM treatment, followed by the CSS treatment, with the control displaying the least growth. Terminalia ivorensis and K. gigantea did not follow this pattern and had the greatest growth in the control followed by the CSS, with the PLM treatment yielding the least growth values. For T. superba, growth in height was greatest in the CSS treatment, followed by the PLM treatment, with the control recording the least.

Competition from herbaceous plants from the revegetation approach implemented by the company and lack of adequate weed control after tree planting were observed to be the main driving factors affecting tree survival and growth at the site (Fig. 7 and 8). 

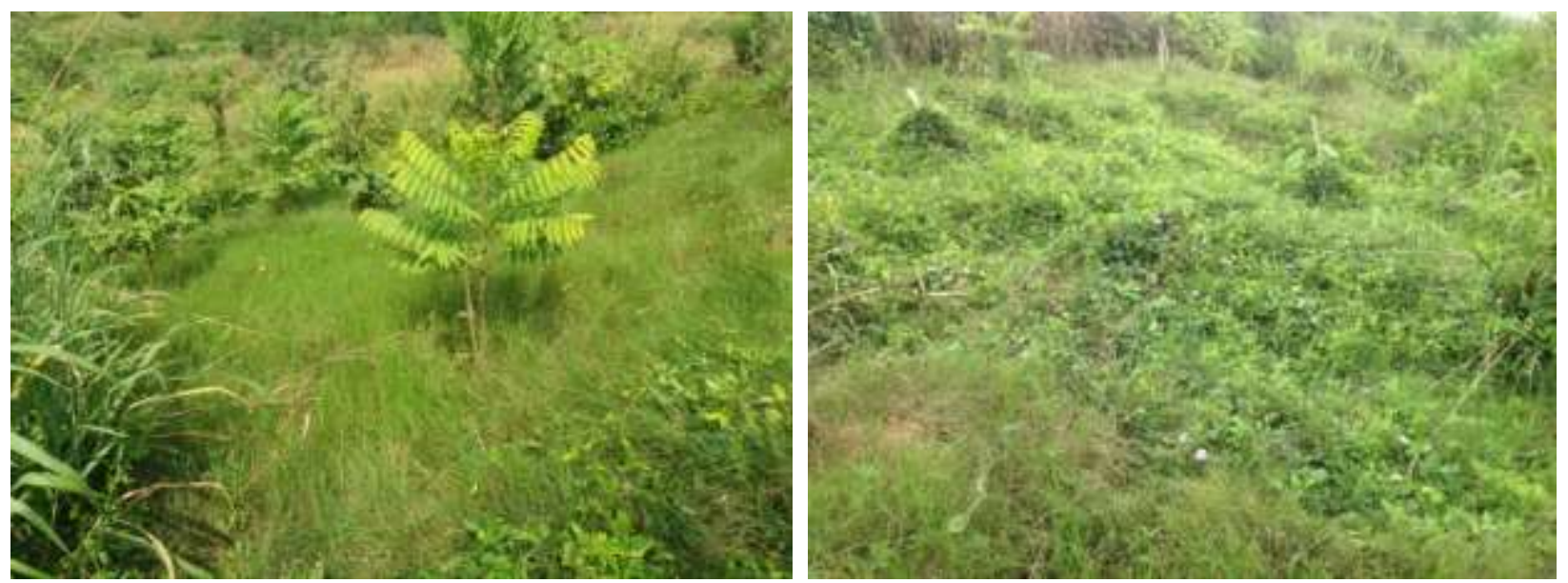

Figure 7. Less competition, high survival (left), strong competition, low survival (right).
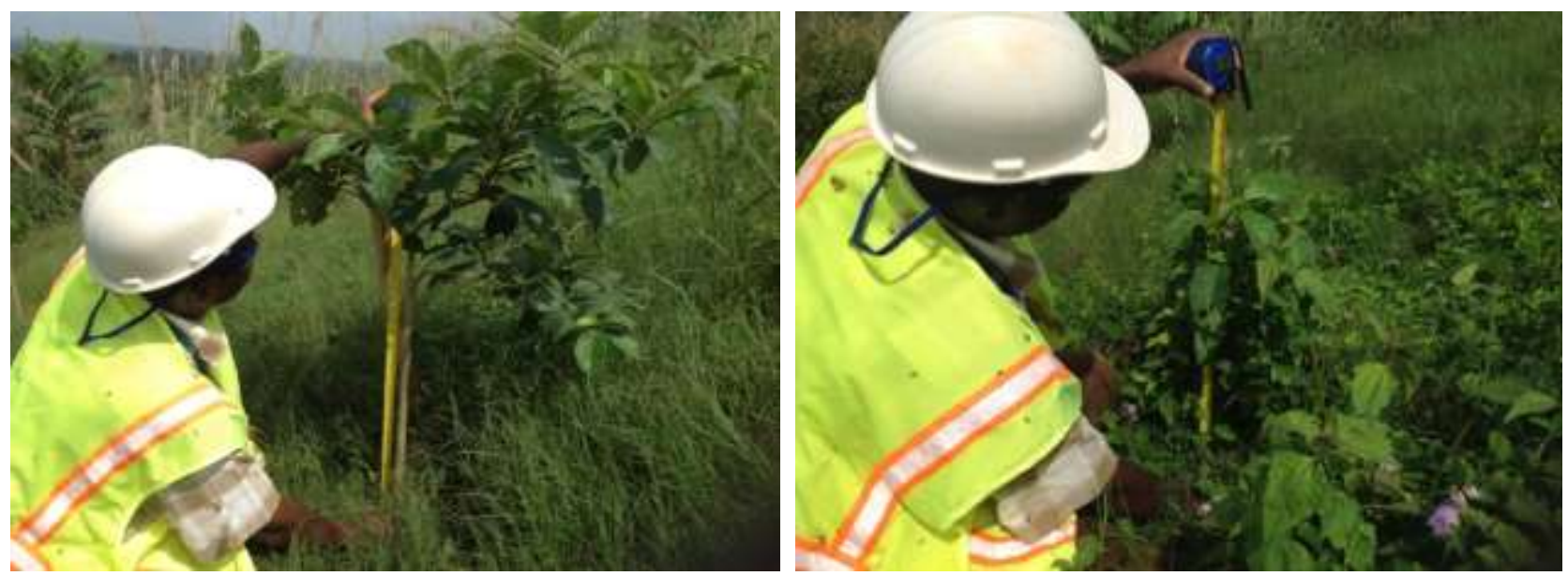

Figure 8. Effect of competition on height growth of $T$. superba seven months after planting in PLM; less competition, fast growth (left $=0.96 \mathrm{~m}$ ), strong competition, slow growth (right $=0.72 \mathrm{~m})$.

\section{Discussion}

Effects of topsoil stockpiling on soil properties

Contrary to our expectations and the first hypothesis, topsoil stockpiling during mining operation at the Amoma Pit did not cause significant adverse impacts on soil properties such as $\mathrm{pH}$, nutrients, OM, EC, ECEC, and base saturation, compared to the REF soil. This finding contrasts with previous studies (Akala and Lal, 2000; CI, 2000; Harris et al. 1989; Visser et al, 1984; Abdul-Kareem and McRae, 1984; DOEC, 2005; and Wright, 2002), that found topsoil stockpiling adversely affected SOM content, nutrients supply, and $\mathrm{pH}$ following land disturbance activities like mining (Reuter, 1997). These three soil parameters are considered the most 
important determinants for the suitability of a site for restoration (Bending et al.,1999). This study, however, revealed that all three parameters were not adversely affected by stockpiling, when compared with the REF. According to DOEC (2005), while baseline data on soil that was obtained before mining operations started can be very valuable at the reclamation stage, the chemical and physical properties are often adversely affected by the mining operations. Nonetheless, a direct comparison between the TSP and a baseline soil data obtained by the Soil Research Institute of Ghana before mining operations (Adu, 2012) likewise showed stockpiling did not generate any adverse changes to soil properties. Further comparisons with guidelines from other studies, as far as reclaimed mine soils (Larney and Angers, 2012; Wall, 2014) and even agricultural soils (Brady and Weil, 2008) are concerned, again demonstrated the properties of the TSP were within the acceptable range for vegetation establishment.

The high SOM content of the STP was mainly attributed to the proper topsoil management (TSM) strategy implemented by NGGL both prior to mining operations and at re-application during reclamation. The company employed the double stripping TSM approach (Wright, 2002) with most of the vegetation biomass, including stumps and root of trees, salvaged and buried in the TSP. This practice helped in the long-term preservation of the TSP quality by generating more SOM, which corresponded to the OC content necessary for soil microbial activity in initiating carbon and nutrient cycling processes (Larney and Angers, 2012). In addition, prior to stockpiling the TSP was covered with BGTs to control erosion (Nsiah and Schaaf, 2018) and seeded with deep-rooted perennial plants, which have been demonstrated to increase biological activities and restore soil structure into the deeper soil profile (Rai et al., 2014; Brady and Weil, 2008; Hamza and Anderson, 2005). Furthermore, the site being in a humid tropical climate with high temperature and moisture (NGGL, 2015) might have promoted continuous cycling of nutrients and $\mathrm{OM}$ accumulation from both above- and below-ground biomass of the perennial plants (Hazelton and Murphy, 2007; Wright, 2002; Brady and Weil, 2008). Moreover, the significantly higher SOM concentration in the TSP compared with the REF was ascribed to the fact that there was no tillage or cultivation within the period of the stockpiling, which made the TSP similar to a fallow land. In contrast, the REF was a cultivated cocoa farm. Therefore, the significantly lower SOM content at the REF site could be attributed to losses through erosion and crop harvesting as well as C oxidation to the atmosphere as carbon dioxide (Brady and Weil, 2008; Six et al., 2002; Schlesinger, 1997). Again, the high SOM concentration in TSP was associated with significantly 
greater $\mathrm{N}$ content in the TSP compared with the REF. The lower SOM and N concentration in the REF soil resulted in a significantly greater $\mathrm{C}: \mathrm{N}$ ratio compared to TSP.

Despite the statistical difference in the recorded ECEC, the calculated BS for both sites was very high. This was anticipated since the $\mathrm{pH}$ values were near neutral, indicating the variable charge from SOM dominated the exchange sites (Hazelton and Murphy, 2007). The average percentage of sand, silt, and clay correlated with the soil texture difference between the TSP (clayloam) and the REF (sandy-clay-loam). The difference in soil texture could be ascribed to more soil erosion at the REF which was a cultivated Cocoa farm compared to the TSP, which behaved more like a fallow land that was well controlled from erosion during the stockpiling period. This is further supported by the fact that the REF contained lesser silt and clay contents than the TSP, since silt and clay are known to be eroded preferentially by rainfall (Rickson, 2006; CI, 2000; Wright, 2002). The low bulk density at the REF, thus correlated with larger fraction of coarse sand particles resulting in larger macro pores compared with the TSP that had more aggregated fine clay particles with more small pores (Brady and Weil, 2008). Notwithstanding the differences, the recorded TSP values for both texture (clay-loam) and bulk density, an indicator for soil compaction, were within the recommend range $\left(1.5-1.7 \mathrm{~g} \mathrm{~cm}^{-3}\right)$ for tree establishment on reclaimed soils (Rollet et al., 2015) as well as that of productive native soils (Brady and Weil, 2008).

Results on topsoil properties after seven years of stockpiling at NGGL were quite distinct from those of a study by Harris et al. (1989) who explored the effects of 3 to 252 months of topsoil stockpiling on microbial activity and physical properties. They found that older stockpiles had poor structure, high bulk density, decreased microbial biomass, lowered soil nitrogen, and decreased organic carbon. The observed decrease in SOM and changes in chemical properties following topsoil stockpiling has been attributed to oxidation reactions by soil microbes (Wells and Potter, 1986;) as well as methods of stripping and piling (Visser et al., 1984), which was properly controlled through the adopted topsoil management strategy at NGGL. The findings of this present study are supported by Rai et al. (2014) who reported less impact on nutrient cycling and microbial activity when plant cover can be maintained with roots extending throughout the depth of topsoil stockpile. 


\section{Effect of organic amendment on tree survival and growth}

Although the analysis of the TSP revealed stockpiling had no adverse impacts on soil properties, i.e. there were no limiting conditions of the seven-year old stockpiled topsoil, the OA was applied in order to test the second hypothesis. Whilst application rates of OA of up to 100 tons per hectare have been recommended (SNIFFER, 2010), the rates are site-specific based on the properties of the amendment materials (AM), such as $\mathrm{C}: \mathrm{N}$ ratio, purpose of application and quality of in-situ material especially, $\mathrm{pH}, \mathrm{OM}$ and nutrients, as well as the intended use of the land following application (Rollet et al., 2015). Analyses of both the PLM and the CSS revealed high nutrient and OM contents with low $\mathrm{C}: \mathrm{N}$ ratios. This coupled with the good quality of the TSP resulted in low application rates of the AMs, which were applied to planted trees only, and not evenly mixed with the entire substrate, as a way of ensuring the nutrient levels were not too excessive (Rollet et al., 2015) or phytotoxic (Darmody et al., 2009).

Although general survival of the planted tree species was not optimal in both assessment periods, this could not be attributed to the effect of the OA since treatments did not differ significantly in any of the individual tree species analyzed. In similar manner, both diameter and height of the same tree species planted within the same treatment plot showed OA amendment had no significant influence on tree growth. Hence, the hypothesis that amendment of the TSP with OAs, CSS, or PLM, will significantly promote survival and growth of planted trees was rejected. As discussed above, the lack of an OA effect on tree survival and growth was chiefly attributed to appropriate TSM strategy adopted by the company prior to the mining operations and reapplication of same during reclamation. The practice generated optimum conditions of the TSP especially the high SOM content, $\mathrm{pH}$ and nutrient levels favorable to plants, which have been demonstrated as the most important determinants of a disturbed site's suitability for restoration or improvement (Bending et al., 1999; Williamson and Johnson, 1990) following land disturbing activities. Another possibility could partly be ascribed to the low application rates of the AMs, which could not cause any further significant improvement to soil conditions and thereby promote the growth and survival of planted trees. This conforms to the findings of Chantigny et al. (1999) who emphasized that despite the fact that application of OM results in immediate increase in SOC, the increase is generally proportional to the amount of carbon applied, and in cases of high background levels, the changes in SOC may not be measurable or detectable following low or moderate application rates of amendment materials (Viaud et al., 2011). 
The main cause of disparities in survival and growth of planted trees were observed to be attributed to the management practices for revegetation adopted by the company, rather than to the OA treatment. Although the final end land use on the waste rock dump was planned to be forestry, the standard revegetation practice being implemented by NGGL was to plant grasses as cover crops in the first year, as part of the slope stabilization activities, before planting the intended forest tree species in the second year. Whereas the practice was observed to work excellent as far as soil stabilization and erosion control was concerned, with the exception of few areas with high concentrated run-off flows (Nsiah and Schaaf, 2018), a major problem of competition from herbaceous ground cover was observed to be the main cause of the low survival and wide growth disparities within same tree species planted on same treatment plots. At the beginning of planting season in the second year (April-May), most of the plots had already been invaded by very fastgrowing grasses and other herbaceous pioneer species. Vegetation at the site had to be manually cleared, in some plots twice, in order to pave way for planting the forest tree seedlings. However, because weed roots were already well established in the soil, the weeds regrew rapidly and overcrowded the planted trees, thus hindering their survival and subsequent growth.

The average survival recorded at the experimental site was observed to be higher than that of the general site that was being reclaimed by the company. This was due to the fact that the present study adopted circle weeding (twice) around trees on the experimental plots as part of weed control. The first circle weeding was carried out six weeks after planting (June, 2016) while the second was conducted seven months after planting (December, 2016). The company on the other hand, undertook first general weed control, in the form of manual weeding with the aid of cutlasses, in August 2016, three months after tree planting, including that of the experimental plots. Weed control was practiced on the experimental plots three times, whereas it was practiced only once on the rest of the reclaimed site within the initial seven months after tree planting and before the major dry season in December. Thus, inadequate weed control resulted in more competition and less tree survival at the general reclamation site compared to that of the experimental plot.

Burger et. al. (2005) also have identified competition from herbaceous ground covers established to control erosion as one of the prevalent problems that have historically confronted reforestation and timber production in reclaimed mine sites in the United States of America. The authors proposed two approaches to overcome the historical challenge and to achieve effective revegetation success based on whether the end land use is forestry or agriculture; the forestry 
reclamation approach (FRA) and the grassland (agronomy) reclamation approach (GRA). According to Burger et al. (2005) the GRA employs fast-growing agricultural grasses and legumes to achieve rapid and complete ground cover; whereas the FRA should adopt a slow-growing, noncompetitive, tree-compatible ground cover that will lead to a lower-growing, less-vigorous, sparse groundcover that allows planted tree seedlings to survive and grow. The approach being implemented currently at NGGL was seen to conform to that of GRA, instead of FRA. While still focusing on the FRA, another strategy being proposed by this study which is anticipated to help contribute to the survival and growth of planted trees is the simultaneous planting of the intended tree species and seeding of grasses and/or other cover crops during the first year. This is because, unlike the United States where the recommendation is originating from (West Virginia) which has temperate climate and plant diversity favoring slow-growing ground cover, that of the current study at NGGL (Ghana) is humid tropical climate associated with high temperatures and precipitation as well as high plant diversity and growth (NGGL, 2015). In addition, the TSP from tropical forest is known to retain a majority of seeds and roots (CI, 2000). That coupled with the optimum temperature and moisture conditions, stimulated sporadic regeneration of the stored seeds and roots of the less-recalcitrant pioneer species following the topsoil replacement. Moreover, the pioneer species were able to utilize the initial resources in the TSP to initiate mineralization that ensured rapid growth of other herbaceous species, thereby contributing to the provision of a high SOM pool via net primary productivity (Larney et al., 2012) in all treatment plots that eventually neutralized any effects from the OMs.

\section{$\underline{\text { Conclusions }}$}

Contrary to the general assertion and belief about the adverse impact of stockpiling on soil properties, this study has demonstrated topsoil salvaging and stockpiling did not cause any significant adverse impacts on soil properties during NGGL's mine operation at the Amoma Pit, thus falsifying the first study hypothesis. This was mainly attributed to the proper TSM strategy implemented by NGGL which generated optimum soil conditions of the TSP. The good substrate conditions provided by the TSP and subsequent best reclamation management practices following replacement such as installation of BGTs, site scarification, and seeding of cover crops (grasses) which were the same in all treatment plots, provided the required nutrients to initiate primary productivity that eventually nullified any potential beneficial effects of the organic amendment. Another possibility was partly ascribed to the low application rates of AMs. Consequently, 
amendment with the PLM and the CSS had no significant effect on the survival and growth of planted tree species during the reclamation process.

Competition from herbaceous ground cover that resulted from the company's revegetation approach of seeding cover crops in the first year and postponing planting of intended tree species until the second year, coupled with lack of adequate weed control were observed to be the main driving factors affecting survival and growth of planted trees at the site. Therefore, planting the intended forest tree species concurrently with the establishment of erosion and sediment control ground cover species in constituting the initial phase of the revegetation process, coupled with adequate weed control are perceived to influence survival and growth of planted trees, rather than the current focus on application of the CSS as OA. Even so, a policy on topsoil salvaging and stockpiling and re-application of same for revegetation, as being implemented by NGGL, is recommended for all mining companies in Ghana as a best management practice. This will go a long way in promoting and guaranteeing responsible mining, thereby redeeming the negative image of the mining industry in Ghana.

\section{Acknowledgements:}

We are grateful to Newmont Ghana Gold Limited for granting access in conducting the field experimentation at their mine site. Thanks to the German Academic Exchange Service (DAAD) and the Government of Ghana Scholarship Secretariat for co-funding this study.

\section{$\underline{\text { Literature Cited }}$}

Abdul-Kareem, A.W. and S.G. McRae. 1984. The effects on topsoil of long-term storage in stockpiles. Plant and Soil 76: 357-363. http://dx.doi.org/10.1007/BF02205593

Adu, R. 2012. Assessment of the potential of reclaimed mined land for Agricultural production. MSc. Dissertation, Dept. of Environmental Science, College of Science, Kwame Nkrumah University of Science and Technology, Kumasi - Ghana.

Akala, V.A. and R. Lal. 2000. Potential of mine land reclamation for soil organic carbon sequestration in Ohio. Land Degradation and Development. 11: 289-297. https://doi.org/10.1002/1099-145X(200005/06)11:3<289::AID-LDR385>3.0.CO;2-Y

Bending, N.A.D., S.G. McRae, and A.J. Moffat. 1999. Soil-forming materials: their use in land reclamation. The Stationery Office, London. 
Bouyoucos, G.J. 1931. The hydrometer as a new method for the mechanical analysis of soils; Soil Science 23:34-352.

Brady N.C. and R. Weil. 2008. The Nature and Properties of Soils, 14th Edition. Prentice Hall. Pearson Education Limited 2008; 1046p.

Burger, J., D. Graves, P. Angel, V. Davis, and C. Zipper. 2005. The forestry reclamation approach. US Office of Surface Mining, Appalachian Regional Reforestation Initiative, Forest Reclamation Advisory Number 2. http://arri.osmre.gov/FRA/Advisories/FRA_No.2.7-1807.Revised.pdf

Chantigny, M.H., D.A. Angers, and C.J. Beauchamp. 1999. Aggregation and organic matter decomposition in soils amended with de-inking paper sludge. Soil Sci. Soc. Am. J. 63: 1214-1221. https://doi.org/10.2136/sssaj1999.6351214x

CI. 2000. Conservation International, Lightening the Lode: A Guide to Responsible Large-scale Mining." http://www.conservation.org/sites/celb/Documents/lode.pdf

Darmody R.G., W.L. Daniels, J.C. Marlin, and D.L. Cremeens. 2009. Topsoil: what is it and who cares? Proceedings America Society of Mining and Reclamation, 2009 pp 237-269 https://doi.org/10.21000/JASMR09010237.

DOEC. 2005. Department of Environmental Conservation, New York State revegetation procedures manual for surface mining reclamation. New York State Department of Environmental Conservation, Division of Mineral Resources. https://www.dec.ny.gov/docs/materials_minerals_pdf/reveg1.pdf

Hamza, M.A. and W.K., Anderson. 2005. Soil compaction in cropping systems: A review of the nature, causes and possible solutions. Soil Tillage Res 82:121-145. https://doi.org/10.1016/j.still.2004.08.009

Hall, J.B. and M.B. Swaine. 1981. Distribution and ecology of vascular plants in the tropical rainforest. Forest vegetation in Ghana. Geobotany / The Hague.

Harris, J.A., P. Birch, and C.K. Short. 1989. Changes in the microbial community and physiochemical characteristics of topsoils stockpiled during opencast mining. Soil Use and Management 5, 161-168. https://doi.org/10.1111/j.1475-2743.1989.tb00778.x

Hazelton P.A. and B.W. Murphy. 2007. Interpreting soil test results. What do all the numbers mean? CSIRO Publishing: Melbourne; NSW Department of Natural Resources. 
Journal American Society of Mining and Reclamation, 2019 Vol.8, No.1

Larney, F.J. and D.A. Angers. 2012. The role of organic amendments in soil reclamation: A review. Can. J. Soil Sci. (2012) 92: 19-38 https://doi.org/10.4141/cjss2010-064

L.I. 1652. 1999. Legislative Instrument 1652, Environmental Assessment Regulation of the Republic of Ghana; http://www.epa.gov.gh/ghanalex/acts/Acts/ENVIRONMENTAL\%20ASSESSMENT\%2 0REGULATION,1999.pdf

Miller, R.M. and R.E. Cameron. 1976. Some effects of soils microbiota on topsoil storage during surface mining. pp131-139. In Transactions of the 4th Symposium on Surface Mining and Reclamation. National Coal Association, Washington.

Motsara, M.R. and R.N. Roy. 2008. Guide to Laboratory Establishment for Plant and Soil Nutrient Analysis. FAO-UNO, 19th ED, Rome-Italy, pp 38-40.

NGGL. 2015. Newmont Ghana Gold Limited, Reclamation and Closure Plan Ahafo South Project, $78 \mathrm{pp}$.

Nsiah P.K. 2008. Promoting sustainable relationship between mining communities and mining industries; the role of environmental impact assessment. MSc. Thesis. Dept. of Material Engineering, KNUST, Kumasi, 106 pp.

Nsiah P.K. 2012. The potentials of Pennisetum purpureum as a biological geotextile and topsoil application to promote biodiversity in quarry site reclamation" at Yongwa, Quarry Life Award Project; http://www.quarrylifeaward.com.gh/sites/default/files/media/gh30_nsiah.pdf

Nsiah, P.K. and W. Schaaf. 2018. The potentials of biological geotextiles in erosion and sediment control during gold mine reclamation in Ghana. Journal of Soils and Sediments, https://doi.org/10.1007/s11368-018-2217-7

Rai, V.K., N.S. Raman, S.K. Choudhary, and S. Rai. 2014. Top Soil Management in Coal Mines: A Paradigm Shift Required in Approach. International Journal of Innovative Research in Advanced Engineering (IJIRAE); Volume 1 Issue 10, pp 448-454. ISSN: 2349-2163.

Reuter, R. 1997. Sewage Sludge as an Organic Amendment for Reclaiming Surface Mine Wastes. Restoration and reclamation review. Student On-Line Journal; Vol. 2, No. 7; 6 pp. https://pdfs.semanticscholar.org/f82f/0120bb4a4ab85f63e1d0b7de3572e38c5cc2.pdf

Rickson, R.J. 2006. Controlling sediment at source: an evaluation of erosion control geotextiles. Earth Surf Proc Land 31:550-560. https://doi.org/10.1002/esp.1368 
Rollett, A., M. Taylor, A. Gleadthorpe, M. Vale, and A. Litterick. 2015. Guidance on suitable organic material applications for land restoration and improvement. Earthcare Technical UK. https://www.sepa.org.uk/media/162859/sepa-soil-formation-guidance-document.pdf

Schlesinger, W.H. 1997. Biogeochemistry-An analysis of global change, 2nd ed., Academic Press, London, UK.

Six, J., R.T. Conant, E.A. Paul, and K. Paustian. 2002. Stabilization mechanisms of soil organic matter: implications for C-saturation of soils. Plant and Soil, 241(2): 155-176. https://doi.org/10.1023/A:1016125726789

SNIFFER., 2010. Code of Practice for the Use of Sludge, Compost and other Organic Materials for Land Reclamation. https://www.claire.co.uk/component/phocadownload/category/8

Stark, J.M. and E.F. Redente. 1987. Production potential of stockpiled topsoil. Soil Science 144(1), 72-76. https://doi.org/10.1097/00010694-198707000-00012

Viaud, V., D.A. Angers, V. Parnaudeau, T. Morvan, and A.S. Menasseri. 2011. Response of organic matter to reduced tillage and animal manure in a temperate loamy soil. Soil Use Manage. 27: 84-93. https://doi.org/10.1111/j.1475-2743.2010.00314.x

Visser, S., J. Fujikjawa, C.L. Griffiths, and D. Parkinson. 1984. Effect of topsoil storage on microbial activity, primary production and decomposition potential. Plant and Soil 82: 4150. https://doi.org/10.1007/BF02220768

Wall, M. 2014. Using quality compost to reclaim land for forestry and biomass. Forestry Commission, Forest Research, Technical Development FCJR104.

Wells, S.G. and L.D. Potter. 1986. Applications of geomorphlogy to reclamation. p.17-40. In C.C. Reith and L.D. Potter (eds.) Principles and methods of reclamation science. University of New Mexico Press, Albuquerque.

Williamson, J.C. and D.B. Johnson. 1990. Determination of the activity of soil microbial populations stored and restored soils at opencast coal sites. Soil Biology and Biochemistry, 22(5): 671-671. https://doi.org/10.1016/0038-0717(90)90014-Q

Wright, M.A. 2002. Practical Guide to Reclamation in Utah; Utah Oil, Gas and Mining; http://www.ecorestoration.montana.edu/mineland/guide/construction/Reclamation_Manu al.pdf-671 